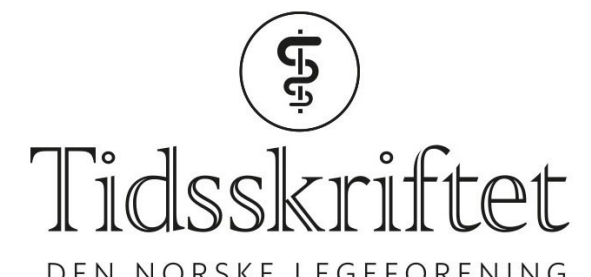

DEN NORSKE LEGEFORENING

\title{
Stakkars tær, stakkars kvinns
}

LEGELIVET

\section{ALEXANDER WAHL}

E-post:alexanderwahl32@gmail.com

Alexander Wahl (f. 1963) er redaktør i primærhelse, Helsebiblioteket, og veileder i allmennmedisin.

Hva er sammenhengen mellom løs mage og skjeve tær?

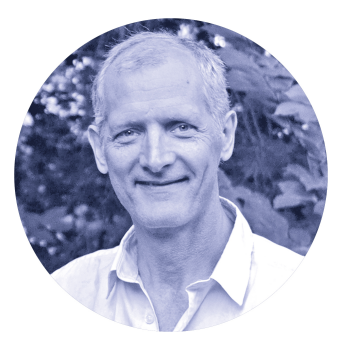

En lidelse er en gåte inntil diagnosen er klar. Min pasient var en elegant, aldrende diplomatfrue, ikledd kasjmir og høye hæler. Hennes problem hørte til gastrointestinaltractus. Det var for mye fart i systemet, med 4-5 tømninger før jobb. Og slik hadde det vært ganske lenge - hun var blitt utredet tidligere. Så jeg begynte å spørre, og hun fortalte. Det finnes dem som har mye å si, og når de merker at tiden er tilmålt, forteller de bare enda mer, enda fortere, med alle detaljer intakt. Så doktorhjernen må begynne å sortere - hva er avgjørende viktig her?

Den første bølge av utredning ble gjort, men jeg kunne ikke rapportere om noen funn da hun kom tilbake til andre konsultasjon. Da begynte jeg å vurdere for eller imot dypere inntrengende utredninger som både er ubehagelige, ressurskrevende og beheftet med ventetid. Men før jeg kom så langt, slengte jeg inn et mellomspørsmål: «Bruker du noen medikamenter som kan påvirke tarmsystemet?» Nei, hun tok ingenting-bortsett fra magnesium, 300-500 mg per dag. Aha, tenkte jeg - dette er årsaken.

«Men hvorfor tar du magnesium?»

«Nei, jeg er så plaget med kramper i leggene og tærne. Plutselig står de og spriker. Jeg må holde dem samlet med trange sko og magnesium.»

Blikket mitt sank ned mot to spisse skotupper - denne ulykksalige moten, denne tvangsmessige hemmingen av det frie liv, denne årelange pinen som omformer en funksjonell, vakker barnefot til et knoklet konglomerat av humper og dumper, som er selve årsaken til kramper i fot og legg, som i sin tur gir opphav til magnesiumbruk og imperiøse toalettbesøk.

Og jeg tenkte på damene i NRK, som smiler kontrollert på høye stiletter, på Utenriksdepartementets fotetikette, som tvangsmessig følger det andre diplomater gjør, og jeg tenkte på min svigermor, min kone og mine døtre og at dette ikke må være sånn. 
For noen ganger er nok nok - en mann må protestere, gå i tog, løfte fanene for kvinnenes undertrykte føtter. Kast av dere forfengelighetens lenker, sett tærne fri, gå barbent i gresset! Spisse sko hører hjemme på karneval og i fetisjismens lønnkammer - det får holde nå, moten må snu. Hvis ikke får dere tuppe meg i ...

Publisert: 18. september 2017. Tidsskr Nor Legeforen. DOI: 10.4045/tidsskr.17.0564

(C) Tidsskrift for Den norske legeforening 2020. Lastet ned fra tidsskriftet.no 